\title{
The Implementation of Passive Removal Granting for Corruption Criminal Acts
}

\author{
Ahmad Nur Kholis*) and Rakhmat Bowo Suharto**) \\ *) Social Advisor at the Class I Correctional Center Semarang, E-mail: \\ nur.achmad@gmail.com \\ ${ }^{* *}$ Faculty of Law, Sultan Agung Islamic University (UNISSULA) Semarang
}

\begin{abstract}
.
Conditional release is one of the rights of every convict who is serving a prison sentence in a Correctional Institution, including convicts of criminal acts of corruption. Since the issuance of Government Regulation Number 99 of 2012, the conditions that must be met in granting parole for convicts of criminal acts of corruption have been tightened on the basis of a sense of community justice. This study aims to examine and analyze the implementation of the provision of parole for convicts of criminal acts of corruption at the Class I Penitentiary in Semarang, as well as the obstacles faced in its implementation. This study uses an empirical juridical approach with analytical descriptive research methods. The data used are primary and secondary data obtained by interview, observation and literature methods. The results of the study concluded that the implementation of the provision of parole for convicts of criminal acts of corruption at the Class I Penitentiary in Semarang was carried out in accordance with the rules of Government Regulation No. 99 of 2012. In practice, not all convicts of criminal acts of corruption can obtain parole because the conditions are not met. Obstacles experienced in the implementation of the provision of parole for convicts of criminal acts of corruption include: convicts are unable to pay fines and/or replacement money, the implementation of social work assimilation must involve third parties as a condition for proposing parole and the existence of information as a justice collaborator from enforcement officers in another law. To overcome these obstacles, it can be done by coordinating and proposing leave before being released.

Keywords: Convicts; Corruption; Parole.
\end{abstract}

\section{Introduction}

Indonesia stands on a legal footing to regulate the life of the nation and state. In the theory and practice of the state, the concept of a state of law "Rechtstaat" is known, the concept of a state of law "Rule of Law", the concept of a state of law "Religy Legality" and "Islamic Nomocracy", the concept of a state of law "Socialist Legality", and for Indonesia based on the concept of "State of law based on Pancasila". ${ }^{1}$ The rule of law in Indonesian terms is formed from two syllables, state and law. The equivalent of this word shows the complementary form and nature between the state on the one hand and the law on the other. ${ }^{2}$

Sentencing in Indonesia cannot be separated from the principle of the rule of law contained in Article 1 paragraph (3) of the 1945 Constitution of the Republic of

\footnotetext{
${ }^{1}$ Aloysius R. Entah, “Indonesia Negara Hukum yang Berdasarkan Pancasila”, L Research Rev.Q. Volume 2 No 4 (2016) url: https://journal.unnes.ac.id/sju/index.php/snh/article/view/21340 ${ }^{2}$ Majda El Muhtaj, 2005, Hak Asasi Manusia dalam Konstitusi Indoensia (Dari UUD 1945 Sampai Dengan Perubahan UUD 1945 Tahun 2002), Jakarta: Kencana Prenada Media Group, p. 17.
} 
Indonesia in this case the duty to protect all the interests of the nation by providing protection and welfare for every citizen. Imprisonment is the last resort in the criminal law system, therefore in its implementation it must refer to human rights considering that prisoners have basic rights that must be protected ${ }^{3}$.

Along with the times, the change in perspective on the treatment of prisoners in Indonesia is an evaluation of humanity which is a manifestation of the noble values of Pancasila, as the basis for the nation's view of life that recognizes human rights. Saharjo as a reformer in the world of prisons in Indonesia, has put forward the idea of penalization for convicts, namely: 1) Everyone is a social being; 2) No one lives outside the community; 3 ) Convicts are only sentenced to lose their freedom of movement. ${ }^{4}$ In order for the purpose of sentencing to have a positive impact on the development of prisoners, sentencing must be associated with social and cultural values that live in society. The correctional system is one of the renewal options in the implementation of prison sentences which contains new efforts to implement prison sentences and new ways of treating prisoners based on humanitarian principles.

Based on this thought, since 1964 the system of coaching for prisoners and criminal children has undergone a fundamental change, namely from the prison system to the correctional system. Likewise, the institution which was originally called a prison house and a state education house (Centrale Ge Vangenis) became a Correctional Institution based on the Instruction of the Head of the Prison Service Number: JHG8/506 dated June 17, 1964. ${ }^{5}$ The change in the paradigm of the place of punishment from prison to correctional institution as stipulated in Act No. 12 of 1995 concerning Corrections brings juridical consequences in the form of changing the purpose of punishment from retaliation to coaching. ${ }^{6}$

The correctional system is an arrangement regarding the direction and boundaries as well as the method of fostering Correctional Inmates based on Pancasila which is carried out in an integrated manner between the coaches, those who are fostered and the community to improve the quality of Correctional Inmates so that they are aware of their mistakes, improve themselves, and do not repeat criminal acts so that they can be readmitted. by the community, can play an active role in development, and can live naturally as good and responsible citizens. ${ }^{7}$ This theory is divided into two groups, namely Correctional Institutions as a forum for fostering prisoners and the role of society in fostering prisoners. ${ }^{8}$

\footnotetext{
${ }^{3}$ Chuasanga A., Ong Argo Victoria. 2019. "Legal Principles Under Criminal Law in Indonesia and Thailand", Jurnal Daulat Hukum, Vol 2, No 1 (2019) http://jurnal.unissula.ac.id/index.php/RH/article/view/4218

4Petrus Irwan Panjaitan \& Pandapotan Simorangkir, 1995, Lembaga Pemasyarakatan Dalam Persfektif Sistem Peradilan Pidana, Jakarta: Pustaka Sinar Harapan, p. 13.

5 Direktorat Jenderal Pemasyarakatan, 2009, Cetak Biru pembaharuan Sistem Pemasyarakatan, Jakarta.

${ }^{6}$ Adami Chazawi, 2002, Pelajaran Hukum Pidana Bagian I, Stelsel Pidana, Tindak Pidana, Teori-teori Pemidanaan \& Batas Berlakunya Hukum Pidana, Jakarta: Raja Grafindo Persada, p. 38.

${ }^{7}$ Article 1 number 2 of Act No. 12 of 1995 concerning Corrections.

${ }^{8}$ C.D Jisman Samosir, 2012, Sekelumit Tentang Penologi dan Pemasyarakatan, Bandung: Nuansa Aulia, p. 128.
} 
In the blueprint document for the renewal of the implementation of the correctional system in 2009, Chapter II emphasized that social reintegration is the philosophy of punishment that underlies the implementation of the correctional system, which states that "philosophically, correctional facilities are a criminal system that has moved far away from the retributive philosophy (retaliation) deterrence, and resocialization. Correctional is in line with the philosophy of social reintegration by assuming that crime is a conflict that occurs between the convict and the community. So that sentencing (punishment) is intended to restore conflict or reunite the convict with the community (reintegration). ${ }^{9}$

The penitentiary system places prisoners as individuals and ordinary citizens, so that the treatment given is not based on retaliation but rather on coaching and guidance. With the guidance and guidance provided, it is hoped that after serving the criminal period, the prisoners concerned can return to society and can become useful human beings for society, nation and state. ${ }^{10}$

Act No. 12 of 1995 concerning Corrections states that prisoners have the right to Remission, Assimilation inside and outside the prison walls, Conditional Release and Leave Before Free (Integration Development).

Conditional release is the right of all convicts, including convicts of criminal acts of corruption. Corruption is included in the category of extraordinary crime, this is related to the losses experienced as a result of the crime. Corruption deviations can in the form of harming state finances, bribery, embezzlement in office, extortion, fraudulent acts, conflicts of interest in procurement and gravity. ${ }^{11}$

Conditional release for convicts of corruption crimes is not imaginary to cause pros and cons among the public. The community wants the perpetrators of criminal acts of corruption to be punished as severely as possible, including in order not to get parole, but on the other hand, parole is the right for every prisoner, including convicts of criminal acts of corruption. Starting from this idea, on the basis of a sense of community justice, Government Regulation number 99 of 1999 was issued with the hope of being able to tighten the granting of rights for prisoners which are included in extraordinary crimes including corruption.

The tightening of conditional release for convicts who are perpetrators of criminal acts of corruption raises questions about how the implementation of these restrictions at the Class I Penitentiary in Semarang, the obstacles experienced, and the efforts made to overcome these obstacles.

This paper aims to examine and analyze the implementation of the provision of parole for convicts of criminal acts of corruption at the Class I Penitentiary in Semarang, as well as the efforts made to overcome the obstacles faced.

\section{Research Methods}

\footnotetext{
9Iqrak Sulhin, “Filsafat (sistem) Pemasyarakatan”, Jurnal Kriminologi Indonesia, Vol. 7 No. 1 (2011) url: http://journal.ui.ac.id/index.php/iki/issue/view/199

${ }^{10}$ Soedjono Dirjosisworo, 1984, Sejarah dan Asas-Asas Penologi, Bandung: Armico, p. 199-200.

11 Endah Dwi Winarni, "Pertanggungjawaban Pidana dalam Pengelolaan Dana Desa Berdasarkan PP Nomor 8 Tahun 2016", Jurnal Daulat Hukum Vol. 1 No. 1 (2018) url: http://jurnal.unissula.ac.id/index.php/RH/article/view/2646/1990
} 
This study uses an empirical juridical approach, which is a method and procedure used to solve research problems by examining secondary data first and then proceeding with conducting research on primary data in the field. ${ }^{12}$ This research uses descriptive analytical research method, namely describing the applicable laws and regulations related to legal theories and practice of implementing laws and regulations. ${ }^{13}$ The source of the data used is the primary data source from the Class I Penitentiary in Semarang through interviews, observation and other data collection. Sources of secondary data obtained by the library method. Secondary data sources come from primary materials and secondary materials. The primary material was obtained from laws and regulations concerning correctional facilities and the implementation of the rights of prisoners in prison such as laws, government regulations, ministerial regulations, while the secondary materials were obtained from text books, legal journals, legal dictionaries and comments. These data were analyzed qualitatively using the theory of law enforcement.

\section{Results and Discussion}

\subsection{Conditional Release for Corruption Convicts}

The law should really guarantee social justice. The formulation of the rights and obligations of citizens before the law is the embodiment of one of the principles of the Republic of Indonesia, namely the principle of social justice. ${ }^{14}$ In essence, the law contains ideas or concepts regarding justice, certainty and social benefits. According to Immanuel Kant, "Understanding the rule of law as a security guard state (nachtwakersstaat). That is, the state is tasked with maintaining public order and security" so that a law enforcement system must be created, one of which is in Indonesia, with a legal structure that includes related institutions and plays a role in (judicial system) law enforcement (investigators, prosecutors, courts, defenders), legal substance includes laws and regulations governing criminal and civil acts (formal and material), 15

Law enforcement is the entire activity of implementing law enforcement, justice, and protection of human dignity, peace and legal certainty, in accordance with the 1945 Constitution. ${ }^{16}$ Speaking of law enforcement in Indonesia, There are four subsystems that build the criminal justice system in Indonesia, namely the police as investigators, prosecutors as prosecutors, courts (judges) as breaker and correctional institutions. As a system, the four sub-systems are interrelated and influence each other. The process of resolving criminal cases begins with an

\footnotetext{
${ }^{12}$ Ronny Hanitijo Soemitro, 1990, Metode Penelitian Hukum dan Jurimetri, Jakarta: Ghalia Indonesia, p. 10.

13Ibid., p. 97-98.

${ }^{14}$ Shidarta (ed), 2012, Mochtar Kusuma-Atmaqja dan Teori Hukum Pembangunan Eksistensi dan Implikasi, Jakarta: Epistema Institute, p. 214.

${ }^{15}$ H.A. Rusman, 2017, Krimimalistik Mengungkap Kejahatan Sesuai Fakta, Cianjur: Unsur Press, p. 19.

${ }^{16}$ Soerjono Soekanto, 1986, Faktor-faktor Yang Mempengaruhi Penegakan Hukum, Jakarta: Rajawali, p. 5.
} 
investigation by an investigator, a prosecution by a public prosecutor (prosecutor), then trial in court to obtain a decision from the judge. After the judge's decision is declared to have obtained permanent legal force (inkracht van gewijsde), the decision will be carried out by the prosecutor by placing the convict in a correctional institution. Furthermore, the penitentiary will provide guidance to inmates (inmates) before being returned to the community. ${ }^{17}$

When the convict has finished serving his criminal period, he will return to society. But the return of prisoners to society is not only because they have spent their criminal period in a correctional institution. It could be that they returned to society because they were given a social reintegration program through parole, leave before release or conditional leave.

The provision of parole for convicts of criminal acts of corruption is regulated in Government Regulation number 99 of 2012 amendments to Government Regulation number 32 of 1999. The implementation of Government Regulation number 99 of 2012 is regulated in more detail in Regulation of the Minister of Law and Human Rights number 03 of 2018.

The birth of Government Regulation number 99 of 2012 was motivated by demands for a sense of community justice. ${ }^{18}$ In order for the granting of rights to convicts who perpetrate this particular crime can provide a sense of justice in the community, it is necessary to "tighten" the granting of rights to inmates, with the issuance of Government Regulation No. 99 of 2012 is expected to be able to tighten the granting of rights for prisoners including WBP criminal acts. corruption that is included in the Extra Ordinary Crime.

Based on Ministerial Regulation number 03 of 2018, granting parole to convicts of criminal acts of corruption is different from convicts of general crimes. Convicts of general crimes can be given parole after serving 2/3 of the criminal period, having good behavior for at least the last 9 (nine) months, participating in the coaching program in prison with a good predicate and the community accepts the parole. Meanwhile, convicts of criminal acts of corruption can be given parole if they meet the requirements as convicts of general crimes and are tightened with the addition of other conditions, namely having undergone social work assimilation for of the remaining criminal period (social work assimilation is given after convicts have served $2 / 3$ of the term).

The party authorized to grant parole is the Minister of Law and Human Rights of the Republic of Indonesia. The process for granting parole is as follows:

- The Correctional Observer Team (TPP) after hearing the opinions of TPP members and studying progress reports from the Correctional Guardian, provides recommendations to the Head of the Correctional Institution regarding the proposal for parole of prisoners.

- If the Head of the Correctional Institution agrees with the recommendation, then the Head of the Correctional Institution proposes parole to the Director General of Corrections by first sending it to the Regional Office for verification.

\footnotetext{
${ }^{17}$ Berlian Simarmata, "Pemberian Remisi Terhadap narapidana Koruptor dan Teroris", Mimbar Hukum Volume 23 No. 3 (2011) url: https://jurnal.ugm.ac.id/jmh/issue/view/2159

${ }^{18}$ Admin Direktorat Jenderal Pemasyarakatan, Rambu-rambu Sosialisasi PP Nomor 99 Tahun 2012, Jakarta (http://www.ditjenpas.go.id/article/article.php?id=288)
} 
- After being verified at the Regional Office, the proposal is forwarded to the Directorate General of Corrections for re-verification.

If all conditions (administrative and substantive) are met, the Director General of Corrections on behalf of the Minister of Law and Human Rights issues a decision to grant parole. When undergoing parole, inmates are required to follow the guidance and supervision of the Correctional Center until their prison sentence is over and a probationary period of 1 (one) year is added. ${ }^{19}$

\subsection{Implementation of the Granting of Conditional Release for Convicts of Criminal Acts of Corruption in Class I Penitentiary Semarang}

Class I Penitentiary Semarang is one of the Technical Implementing Units (UPT) in the field of Corrections, including in the work area of the Regional Office of the Ministry of Law and Human Rights in Central Java.

One of the duties and functions of the Class I Penitentiary in Semarang is to carry out the development of prisoners and students. In its implementation, the coaching of prisoners in the Correctional Institution is divided into three stages of development, namely: early stage coaching, advanced stage coaching and final stage coaching. In this final stage of development, prisoners who meet the requirements are given parole and the guidance is carried out outside the Correctional Institution by the Correctional Center called Correctional Client Guidance.

Based on an interview with the Head of the Community Guidance Section for Class I Prisons in Semarang, the prisoners for corruption crimes proposed for parole during 2021 amounted to 11 people with a total number of convicts for corruption crimes as many as 103 people.

In connection with the tightening of conditions for granting parole for convicts of criminal acts of corruption as stipulated in Government Regulation No. 99 of 2012, the proposal for parole for convicts of criminal acts of corruption in the Class I Prison in Semarang is carried out for those who have met the requirements as stipulated in the government regulation. For convicts of criminal acts of corruption who cannot pay fines and/or replacement money, they are still given the right of integration through leave before being released. This is given to convicts of criminal acts of corruption who are unable to pay fines and/or replacement money or the relevant legal apparatus does not issue justice collaborator information for them.

Based on interviews with officers from the Semarang Class I Penitentiary, it was obtained information that briefly the process of applying for parole for convicts of criminal acts of corruption is as follows:

- After the convict is deemed successful in undergoing the coaching process up to $1 / 2$ the criminal period, the inmate is allowed to apply for parole by attaching a statement from the convict not to repeat the unlawful act, a

\footnotetext{
${ }^{19}$ Timbul Marangatua Simbolon, "Analysis The Role Of Correctional Center (Bapas) The Excemption Conditional", Jurnal Daulat Hukum Vol. 1 No. 3 (2018) url: https/jurnal.unissula.ac.id/index.php/RH/article/3404/2513
} 
statement and guarantees from the family known by the village head where the guarantor's family is domiciled.

- Submission of Community Research to the Fathers Center by attaching the following documents:

- Copy of minutes of execution of court decisions and excerpts of court decisions;

- $\quad$ Copy of the change list;

- PB calculation list;

- F registers;

- Guarantee letter from guarantor; and

- Copy all documents in point 1 (one).

- After the Fathers issued the Community Research document, the prisoners were included in the prison TPP trial.

- If the head of the prison, taking into account the results of the prison TPP trial, approves the inmate to be proposed for parole, then parole is proposed through the Correctional Database System (SDP) application and sent directly to the Directorate General of Corrections.

- After the data is sent, the data will go to the Regional Office SDP for verification first and after verification it will go to the SDP Directorate General of Corrections.

- After entering the SDP, the Directorate General of Corrections will check documents related to administrative and substantive requirements and then conduct a TPP trial.

- Recommendations for the TPP trial are submitted to the director general of prisons and a decision is issued on granting parole.

- After the decision to grant parole is issued, the prison prints the decision document and then implements it.

- The implementation of parole is carried out with the following conditions:

- The implementation of parole starts from the date as stated in the list of attachments to the parole decree.

- Reporting to the local District Attorney by attaching a cover letter and handover from the prison, a copy of the parole decree, the prisoner's parole letter. As evidence of reporting, the prosecutor will issue a letter P-52.

- Report to the local police station by attaching a copy of the parole decree.

- Report to the local Bapas by attaching a cover letter and handover document from the prison, a copy of the parole decree, the prisoner's parole letter, the P-52 letter from the prosecutor's office. After that, until the end of the probationary period (according to the attachment to the parole decree) prisoners are required to report to the BAPs once a month.

The obstacles faced by the Class I Penitentiary in Semarang in implementing parole for convicts of criminal acts of corruption are as follows:

- Prisoners who are unable to pay the fine and/or replacement money cannot be proposed for parole.

- The relevant legal apparatus does not issue a certificate of inmates who are willing to work together to help uncover the crimes committed (justice collaborator). 
follows:

Efforts that can be made to overcome the obstacles mentioned above are as

- Prisons carry out awareness building for prisoners to follow the coaching program properly. Make a statement so that the prisoner can be submitted first to get parole.

- Prisons coordinate with Regional offices and the Directorate General of Corrections regarding regulations on parole.

- Prisons coordinate with relevant law enforcement officers in order to request information that prisoners are willing to work together to help uncover the crimes they have committed.

- If the prisoner is unable to pay the fine and/or replacement money or does not get information that is willing to help uncover criminal acts committed by other law enforcement officers, the inmate is advised to propose leave before being released.

- If convicts of criminal acts of corruption cannot meet the administrative and substantive requirements, they will still be given mental guidance and encouragement so that they can carry out the criminal justice until the end of their sentence properly.

\section{Clossing}

Based on the discussion above, it can be concluded that the implementation of parole for convicts of criminal acts of corruption at the Class I Penitentiary in Semarang is carried out in accordance with Government Regulation Number 99 of 2012 whose implementation is regulated in the Regulation of the Minister of Law and Human Rights Number 03 of 2018.For convicts of criminal acts of corruption who cannot be given parole, they are given Leave Before Free and good coordination is needed between prisons and Regional Offices and the Directorate General of Corrections regarding rules and policies. Prisons also continue to coordinate with relevant law enforcement officials in order to request information that prisoners are willing to work together to help uncover the crimes they have committed.

\section{References}

\section{Journals:}

[1] Admin Direktorat Jenderal Pemasyarakatan, Rambu-rambu Sosialisasi PP Nomor $99 \quad$ Tahun 2012, Jakarta (http://www.ditjenpas.go.id/article/article.php?id=288)

[2] Aloysius R. Entah, "Indonesia Negara Hukum yang Berdasarkan Pancasila”, L Research Rev.Q. Volume 2 No 4 (2016) url: https://journal.unnes.ac.id/sju/index.php/snh/article/view/21340

[3] Berlian Simarmata, "Pemberian Remisi Terhadap narapidana Koruptor dan Teroris", Mimbar Hukum Volume 23 No. 3 (2011) url: https://jurnal.ugm.ac.id/jmh/issue/view/2159 
[4] Chuasanga A., Ong Argo Victoria. 2019. "Legal Principles Under Criminal Law in Indonesia and Thailand", Jurnal Daulat Hukum, Vol 2, No 1 (2019) http://jurnal.unissula.ac.id/index.php/RH/article/view/4218

[5] Endah Dwi Winarni, "Pertanggungjawaban Pidana dalam Pengelolaan Dana Desa Berdasarkan PP Nomor 8 Tahun 2016”, Jurnal Daulat Hukum Vol. 1 No. 1 (2018) url: http://jurnal.unissula.ac.id/index.php/RH/article/view/2646/1990

[6] Iqrak Sulhin, "Filsafat (sistem) Pemasyarakatan", Jurnal Kriminologi $\begin{array}{llllll}\text { Indonesia, } & \text { Vol. } & 7 & \text { No. } & 1 & \text { (2011) url: }\end{array}$ http://journal.ui.ac.id/index.php/jki/issue/view/199

[7] Timbul Marangatua Simbolon, "Analysis The Role Of Correctional Center (Bapas) The Excemption Conditional”, Jurnal Daulat Hukum Vol. 1 No. 3 (2018) url: https/jurnal.unissula.ac.id/index.php/RH/article/3404/2513

\section{Books:}

[1] Adami Chazawi, 2002, Pelajaran Hukum Pidana Bagian I, Stelsel Pidana, Tindak Pidana, Teori-teori Pemidanaan \& Batas Berlakunya Hukum Pidana, Jakarta: Raja Grafindo Persada

[2] C.D Jisman Samosir, 2012, Sekelumit Tentang Penologi dan Pemasyarakatan, Bandung: Nuansa Aulia

[3] Direktorat Jenderal Pemasyarakatan, 2009, Cetak Biru pembaharuan Sistem Pemasyarakatan, Jakarta.

[4] Direktorat Jenderal Pemasyarakatan, (009, Himpunan Peraturan tentang Pemasyarakatan, Jakarta.

[5] H.A. Rusman, 2017, Krimimalistik Mengungkap Kejahatan Sesuai Fakta, Cianjur: Unsur Press

[6] Majda El Muhtaj, 2005, Hak Asasi Manusia dalam Konstitusi Indoensia (Dari UUD 1945 Sampai Dengan Perubahan UUD 1945 Tahun 2002), Jakarta: Kencana Prenada Media Group

[7] Petrus Irwan Panjaitan \& Pandapotan Simorangkir, 1995, Lembaga Pemasyarakatan Dalam Persfektif Sistem Peradilan Pidana, Jakarta: Pustaka Sinar Harapan

[8] Ronny Hanitijo Soemitro, 1990, Metode Penelitian Hukum dan Jurimetri, Jakarta: Ghalia Indonesia

[9] Shidarta (ed), 2012, Mochtar Kusuma-Atmaqja dan Teori Hukum Pembangunan Eksistensi dan Implikasi, Jakarta: Epistema Institute

[10] Soedjono Dirjosisworo, 1984, Sejarah dan Asas-Asas Penologi, Bandung: Armico

[11] Soerjono Soekanto, 1986, Faktor-faktor Yang Mempengaruhi Penegakan Hukum, Jakarta: Rajawali

\section{Regulation:}

[1] Act No. 12 of 1995 concerning Corrections

[2] Government Regulation Number 99 of 2012 concerning the Second Amendment Number 32 of 1999 concerning Terms and Procedures for the Implementation of the Rights of Correctional Inmates 
[3] Regulation of the Minister of Law and Human Rights Number 03 of 2018 concerning Terms and procedures for granting remission, assimilation, leave to visit family, parole, leave before release and conditional leave 